\title{
Who Cares and How Much? The imputed economic contribution to the Canadian healthcare system of middle-aged and older unpaid caregivers providing care to the elderly
}

\author{
Marcus J. Hollander, Guiping Liu and Neena L. Chappell
}

anadians provide significant amounts of unpaid care to elderly family members and friends with long-term health problems. While some information is available on the nature of the tasks unpaid caregivers perform, and the amounts of time they spend on these tasks, the contribution of unpaid caregivers is often hidden. (It is recognized that some caregiving may be for short periods of time or may entail matters better described as "help" or "assistance," such as providing transportation. However, we use caregiving to cover the full range of unpaid care provided from some basic help to personal care.) Aggregate estimates of the market costs to replace the unpaid care provided are important to governments for policy development as they provide a means to situate the contributions of unpaid caregivers within Canada's healthcare system.

The purpose of this study was to obtain an assessment of the imputed costs of replacing the unpaid care provided by Canadians to the elderly. (Imputed costs is used to refer to costs that would be incurred if the care provided by an unpaid caregiver was, instead, provided by a paid caregiver, on a direct hour-for-hour substitution basis.) The economic value of unpaid care as understood in this study is defined as the cost to replace the services provided by unpaid caregivers at rates for paid care providers.

\section{Methods and Data Sources}

The primary source of data used for the analyses in this study was the 2002 General Social Survey (GSS) conducted by Statistics
Canada (2002). The unit cost data were obtained through a custom data request made to Statistics Canada for hourly wages for different categories of workers from the Statistics Canada (2007) Labour Force Survey (LFS).

The sample for the 2002 GSS was selected from a followup of respondents to the Canadian Community Health Survey (Statistics Canada 2001). Statistics Canada separated the unpaid caregivers in the 2002 survey into two categories, those aged 45-64 and those aged 65+. While efforts were made to combine the two data sets into one data set for caregivers aged 45 or older, this was not feasible due to some incompatibilities in the data. Thus, in this report, we present data for the 2002 survey separately for caregivers in the 45-64 and 65+ age groups.

With regard to costing, most studies (Harrow et al. 2004; Langa et al. 2002a, 2002b; Moore et al. 2001) use hourly wages for their unit costs. This may be appropriate from the perspective of an opportunity cost, traditional economic evaluation; however, in the real world, paid care is usually provided through regulated, and insured, care provider organizations that provide care, supervision and quality assurance functions. In Canada, most formal care is provided through legally constituted care provider organizations. Thus, if governments wish to replace unpaid care with paid care, they would have to pay the market rates charged by such organizations. The alternative (where one could cost unpaid care time at the equivalent of salary rates) would be to have the unpaid caregiver effectively become a case 
manager who would have to hire and fire worker directly and organize and manage all paid care services. This would be quite onerous, particularly for elderly caregivers who may also have functional limitations, or for middle-aged caregivers who may have significant family and employment obligations. Thus, it is our view that market rates, or some proxy of market rates, should be used to calculate the imputed costs of unpaid care.

With regard to calculating unit costs, we developed a methodological approach to calculate market rates from hourly salaries (hourly salaries are wages received by the worker, such as $\$ 12$ per hour, whereas market rates are the rates a care provider organization would charge a care recipient). Market rates include factors such as benefits, administrative costs, capital costs and so on. It was necessary to calculate estimated market rates as there is no publicly available national data on the market rates charged by home care provider organizations. We estimated that a factor of 1.8 would be appropriate to convert hourly salaries to market rates (e.g., a home support worker who receives $\$ 12.50$ per hour would have an estimated billable market rate of \$22.50). Our approach was compared with market rates for a national purchaser of home care services and was found to produce similar billable hourly rates for different types of care providers.

Four estimates were calculated for this study. One estimate was based on hourly salaries by type of provider (from the LFS [Statistics Canada 2007]). The second estimate was based on the hourly salary of home support workers from the LFS. This estimate was used on the basis that most of the services to clients could be provided by a well-trained home support worker. The third estimate was based on market rates by type of provider. The fourth estimate was based on market rates for home support workers. Given that most services can be provided by a home support worker and that paid care provision is usually provided through home care agencies, at market rates, it is our view that this approach provides the most realistic imputed costs for substituting paid care for unpaid care.

The groupings of types of care provision and unit costs based on hourly salaries (from the LFS [Statistics Canada 2007]), were as follows:

- Meal preparation and cleanup, house cleaning or laundry and sewing: \$12.91 per hour (rate for visiting homemaker, housekeeper and other related occupations)

- House maintenance or outdoor work: $\$ 18.18$ per hour (rate for residential and commercial installers and services)

- Shopping for groceries or other necessities, providing transportation or doing banking or bill paying: $\$ 14.93$ per hour (a pro-rated and blended rate for homemakers [\$12.91], taxi and limousine drivers [\$14.06] and financial auditors and accountants [\$27.74])

- Assistance with bathing, toileting, care of toenails/ fingernails, brushing teeth, shampooing and hair care or dressing (i.e., personal care services): $\$ 21.63$ per hour (rate for registered nursing assistants/licensed practical nurses)

There was considerable methodological complexity in analyzing the data from the 2002 GSS and developing unit costs. The interested reader is referred to the full report prepared for Human Resources and Skills Development Canada (HRSDC) (Hollander et al. 2008) for a description of the methods used, data and methodological limitations, and other technical matters.

\section{Literature Scan}

In this section, we report on the findings of a number of other 
Table 1. Gender, age and marital status of caregivers and care receivers

\begin{tabular}{|c|c|c|c|c|}
\hline \multirow[t]{2}{*}{$\begin{array}{l}\text { Age } \\
\text { Groups }\end{array}$} & & \multirow[t]{2}{*}{ Socio-demographic Categories } & \multicolumn{2}{|c|}{$\begin{array}{l}\text { Estimated } \\
\text { Caregivers in } \\
\text { Canada }\end{array}$} \\
\hline & & & $n$ & $\%$ \\
\hline \multirow{12}{*}{$\begin{array}{l}\text { Caregivers* } \\
\text { aged } 45-64\end{array}$} & \multirow[t]{3}{*}{ Gender } & Males & 857,599 & 48.7 \\
\hline & & Females & 901,779 & 51.3 \\
\hline & & Total & $1,759,378$ & 100.0 \\
\hline & \multirow[t]{5}{*}{ Age } & $45-49$ & 573,971 & 32.6 \\
\hline & & $50-54$ & 526,288 & 29.9 \\
\hline & & $55-59$ & 394,465 & 22.4 \\
\hline & & $60-64$ & 264,653 & 15.0 \\
\hline & & Total & $1,759,378$ & 100.0 \\
\hline & \multirow[t]{4}{*}{ Marital status } & Married/common law & $1,375,837$ & 78.3 \\
\hline & & Separated/divorced/widowed & 248,060 & 14.1 \\
\hline & & Single & 132,160 & 7.5 \\
\hline & & Total & $1,756,055$ & 100.0 \\
\hline \multirow{12}{*}{$\begin{array}{l}\text { Caregivers }^{\dagger} \\
\text { aged } 65+\end{array}$} & \multirow[t]{3}{*}{ Gender } & Males & 126,257 & 41.8 \\
\hline & & Females & 176,037 & 58.2 \\
\hline & & Total & 302,295 & 100.0 \\
\hline & \multirow[t]{5}{*}{ Age } & $65-69$ & 120,420 & 39.8 \\
\hline & & $70-74$ & 89,184 & 29.5 \\
\hline & & $75-79$ & 60,170 & 19.9 \\
\hline & & $80+$ & 32,520 & 10.8 \\
\hline & & Total & 302,295 & 100.0 \\
\hline & \multirow[t]{4}{*}{ Marital status } & Married/common law & 213,055 & 70.5 \\
\hline & & Separated/divorced/widowed & 79,312 & 26.2 \\
\hline & & Single & 9,928 & 3.3 \\
\hline & & Total & 302,295 & 100.0 \\
\hline
\end{tabular}

${ }^{*}$ The number of caregiver survey respondents was 2,985.

TThe number of caregiver survey respondents was 1,026 . topics such as dementia, diabetes and stroke, which are not reported here but can, for the interested reader, be found in the larger HRSDC report.)

An Australian study (Access Economics Pty Limited 2005) on the economic value of unpaid care notes that the amount of unpaid care provided depends on the severity of the functional limitations of the care receiver. The authors also note that over one in eight Australians (some 2.6 million people) were estimated to be providing unpaid care in Australia in 2005, of which 494,000 were primary caregivers who provided most of the care. The authors used several approaches to calculate imputed economic costs. They found that, using an opportunity cost approach (which they defined as the paid work care providers would have undertaken, but for their caregiving responsibilities), the annual economic value of unpaid caregiving would be approximately $A \$ 4.9$ billion. Using a replacement cost valuation approach (similar to the market rate approach used in this study), the value would be $\mathrm{A} \$ 30.5$ billion at estimated market rates. The authors also quantify other costs using a broader economic evaluation perspective. They note that there would have been, in 2005, lost taxes and increased welfare and transfer payments of some A $\$ 969$ million, and costs for the health impacts of sleep disturbances of care providers of approximately A $\$ 1$ billion dollars. Two British articles published by Carers UK (Buckner and Yeandle 2007; Holzhausen 2002) note that the imputed cost of unpaid care in fiscal 2006-2007 was about $£ 87$ billion, more than the annual cost of the British National Health Service, which was $£ 81.7$ billion, for the same fiscal year. Costing for this study was based on billable rates for home care providers rather than the hourly wages of the care providers.

There were a number of articles that estimated the imputed costs of caregiving in the United States (Gibson and Houser 2007a, 2007b; National Family Caregivers national studies and studies on the methodology of costing found in our literature search. (We also found articles on specific
Association and Family Caregiver Alliance 2006). The cost factor in the estimates was an average of market rates and wage 
Table 2. The relationships between caregivers and care receivers*

\begin{tabular}{|c|c|c|c|c|}
\hline \multirow[t]{2}{*}{ Care was received by: } & \multicolumn{2}{|c|}{$\begin{array}{c}\text { Caregivers Aged } \\
45-64\end{array}$} & \multicolumn{2}{|c|}{$\begin{array}{l}\text { Caregivers } \\
\text { Aged 65+ }\end{array}$} \\
\hline & $n$ & $\%$ & $n$ & $\%$ \\
\hline Spouse/partner & 24,805 & 1.4 & 70,457 & 23.3 \\
\hline Father & 236,284 & 13.4 & 5,331 & 1.8 \\
\hline Mother & 732,406 & 41.6 & 22,945 & 7.6 \\
\hline Brother & 7,928 & 0.5 & 6,238 & 2.1 \\
\hline Sister & 11,435 & 0.6 & 19,684 & 6.5 \\
\hline $\begin{array}{l}\text { Son/daughter/grandson/granddaughter/ } \\
\text { son- or daughter-in-law }\end{array}$ & 3,136 & 0.2 & 729 & 0.2 \\
\hline Grandfather or grandmother & 12,887 & 0.7 & - & - \\
\hline Father-in-law & 82,983 & 4.7 & 3,056 & 1.8 \\
\hline Mother-in-law & 218,024 & 12.4 & 11,209 & 7.6 \\
\hline Brother-in-law & 9,824 & 0.6 & 4,913 & 2.1 \\
\hline Sister-in-law & 5,410 & 0.3 & 6,046 & 6.5 \\
\hline Uncle & 16,431 & 0.9 & 2,002 & 0.7 \\
\hline Aunt & 50,473 & 2.9 & 4,621 & 1.5 \\
\hline Cousin & 9,034 & 0.5 & 4,646 & 1.5 \\
\hline Close friend & 161,053 & 9.2 & 89,911 & 29.7 \\
\hline Neighbour & 144,338 & 8.2 & 44,750 & 14.8 \\
\hline Other & 32,927 & 1.9 & 5,757 & 1.9 \\
\hline Number of Caregivers & $1,759,378$ & 100.0 & 302,295 & 100.0 \\
\hline
\end{tabular}

* Caregivers could provide care to more than one care receivers

(Gibson and Houser 2007a) also estimated, in 2006, that for California, with a population of 36.5 million people, there were 4 million care providers and that the economic value of caregiving was US $\$ 45$ billion. For Wyoming, with a population of 515,000 , the authors estimated that there were 55,000 caregivers and that the economic value of their contribution was US\$570 million. Separate hourly costs were calculated for each state, again as a blended rate between market rates and salaries, with an overall hourly rate for the United States of US\$9.63.

Two Canadian studies were found on the imputed economic contribution of unpaid caregivers. Fast and Frederick (1999, October) estimated that, for 1996, the replacement costs of the work provided by caregivers was estimated to be between $\$ 5.1$ and $\$ 5.7$ billion for Canada as a whole using costing based on the replacement wages of paid caregivers. In a study looking at the cost-effectiveness of home care, Chappell and her colleagues (2004) found that the amount of time spent by unpaid caregivers increased as care needs increased. For moderately to severely (i.e., nursing home equivalent) disabled home care clients, the annual estimated contribution of caregiver time, costed at market rates, per client, ranged from $\$ 5,221$ to $\$ 31,515$ in Victoria and $\$ 7,373$ to $\$ 13,374$ in Winnipeg.

With regard to more general and methodological articles, Andersson et al. (2002) compared the friction cost model versus the human capital model of calculating costs. In both approaches, one looks at lost gross income during an absence from work - in this case, to care for a family member. The difference in the approaches is that the friction cost approach only considers the time it takes to replace a worker who is

rates. The national average used was US\$9.63 per hour. The National Family Caregiver Association calculated a range of caregiving time and costs across states for 2004. In California, it was estimated that 3.7 billion hours of care were provided by about 3.4 million caregivers, having an annual market value of US $\$ 36.3$ billion. In contrast, Wyoming, with a much smaller population, had 55 million hours of caregiving valued at US\$542 million. The American Association of Retired Persons (AARP) (Gibson and Houser 2007b) estimated that, in 2006, 30-38 million adult caregivers provided an average of 21 hours of care per week at an estimated cost of US\$354 billion. AARP absent from work, whereas the human capital approach costs the full time that the worker is absent from his or her job. (In the published literature, several terms are used to cover the concept of lost income for caregivers, including human capital approach, opportunity costs and lost productivity.) The authors found that when using the friction cost approach, the costs were $18-44 \%$ of the costs using the human capital approach.

Brouwer and colleagues (1998) provided a commentary on the appropriate methods of economic analysis to be used in costing unpaid care. They noted that lost earnings from the patient and care provider should be included in the analysis, but that the 
Table 3. Types of care and frequency of care provision*

\begin{tabular}{|c|c|c|c|c|c|}
\hline \multirow[b]{2}{*}{ Type of Care } & \multirow[b]{2}{*}{ Frequency } & \multicolumn{2}{|c|}{$\begin{array}{c}\text { Caregivers Aged } \\
45-64\end{array}$} & \multicolumn{2}{|c|}{$\begin{array}{l}\text { Caregivers } \\
\text { Aged 65+ }\end{array}$} \\
\hline & & $n$ & $\%$ & $n$ & $\%$ \\
\hline \multirow{5}{*}{$\begin{array}{l}\text { Meal preparation and cleanup, house } \\
\text { cleaning or laundry and sewing }\end{array}$} & Daily & 239,553 & 23.3 & 50,537 & 51.6 \\
\hline & Weekly & 415,408 & 40.5 & 27,300 & 27.9 \\
\hline & Monthly & 274,094 & 26.7 & 13,306 & 13.6 \\
\hline & Less than monthly & 97,903 & 9.5 & 6,827 & 7.0 \\
\hline & Total & $1,026,957$ & 100.0 & 97,970 & 100.0 \\
\hline \multirow[t]{5}{*}{ House maintenance or outdoor work } & Daily & 53,151 & 5.3 & 7,692 & 12.8 \\
\hline & Weekly & 312,516 & 31.0 & 16,978 & 28.2 \\
\hline & Monthly & 432,464 & 42.8 & 27,032 & 44.8 \\
\hline & Less than monthly & 211,460 & 20.9 & 8,606 & 14.3 \\
\hline & Total & $1,009,590$ & 100.0 & 60,308 & 100.0 \\
\hline \multirow{5}{*}{$\begin{array}{l}\text { Shopping for groceries or other } \\
\text { necessities, providing transportation } \\
\text { or doing banking or bill paying }\end{array}$} & Daily & 65,435 & 4.6 & 18,163 & 7.4 \\
\hline & Weekly & 642,285 & 44.8 & 124,399 & 50.7 \\
\hline & Monthly & 545,073 & 38.0 & 77,300 & 31.5 \\
\hline & Less than monthly & 180,514 & 12.6 & 25,511 & 10.4 \\
\hline & Total & $1,433,307$ & 100.0 & 245,374 & 100.0 \\
\hline \multirow{5}{*}{$\begin{array}{l}\text { Personal care - assistance } \\
\text { with bathing, toileting, care of } \\
\text { toenails/fingernails, brushing teeth, } \\
\text { shampooing and hair care or dressing }\end{array}$} & Daily & 113,186 & 25.3 & 47,962 & 60.7 \\
\hline & Weekly & 175,999 & 39.3 & 18,536 & 23.5 \\
\hline & Monthly & 105,302 & 23.5 & 9,196 & 11.6 \\
\hline & Less than monthly & 53,358 & 11.9 & 3,314 & 4.2 \\
\hline & Total & 447,844 & 100.0 & 79,009 & 100.0 \\
\hline
\end{tabular}

*Data on care provided by caregivers (in dyads).

be calculated using the market (replacement) value of the care provided costed as the hourly salary of a paid care provider.

As noted above, there are a range of approaches that can be used in economic evaluations of care for the elderly. Any approach to be taken in costing unpaid care will be, at least partly, based on the audience and the purpose of the evaluation. From an employer's perspective, the friction method may be appropriate. From a more traditional economic analysis perspective, an opportunity cost approach may have merit. For a government interested in considering what it would cost to replace unpaid care with formal, or paid, care, a market rate perspective might be appropriate. In addition to perspective, it should be noted that a full economic evaluation would consider a wide range of factors including the opportunity costs (lost wages) of clients and caregivers, the cost of health impacts on caregivers due to the stress of caregiving, the implications of tax and social welfare costs and other such factors.

While these factors are recognized, our study looks at a more modest subset of activities, that is, caregiver time costed at replacement wages. Thus, this study does not constitute a full and comprehensive economic evaluation. Rather, it adopts the perspective of government that

absence from paid work should be calculated using the friction cost approach. They also discussed the concept of "opportunity costs," which generally refers to the income that could be derived from other activities in which one could engage. With regard to opportunity costs in the context of unpaid care, they noted that the opportunity cost per hour is equal to the wage paid per hour. This is similar to the human capital approach. The authors concluded that in developing cost estimates of the care time contributed by unpaid caregivers, costs should is interested, for future policy development purposes, in what it would cost to substitute paid care for unpaid care, for seniors, by caregivers aged 45 years of age or older. This age limitation was due to the fact that the 2002 GSS only surveyed caregivers aged 45 or older.

\section{Findings and Cost Estimates}

As noted above, there were two separate caregiver files in the 2002 GSS, one for caregivers aged 45-64 and one for caregivers aged 
Table 4. Average hours per week per dyad

\begin{tabular}{|l|c|c|}
\hline Type of Service & Caregivers 45-64 & Caregivers 65+ \\
\hline $\begin{array}{l}\text { Meal preparation and cleanup, house } \\
\text { cleaning or laundry and sewing }\end{array}$ & 7.3 & 16.3 \\
\hline House maintenance or outdoor work & 1.8 & 2.0 \\
\hline $\begin{array}{l}\text { Shopping for groceries or other necessities, } \\
\text { providing transportation or doing banking or } \\
\text { bill paying }\end{array}$ & 2.0 & 2.5 \\
\hline $\begin{array}{l}\text { Assistance with bathing, toileting, care } \\
\text { of toenails/fingernails, brushing teeth, } \\
\text { shampooing and hair care or dressing }\end{array}$ & 4.5 & 11.1 \\
\hline Overall average & 7.9 & 10.4 \\
\hline
\end{tabular}

$37.4 \%$ were aged $55-64$. For the older group, $69.3 \%$ were aged $65-74$ and $30.7 \%$ were 75 years of age or older.

With regard to gender, $48.7 \%$ of the younger caregivers were males and $51.3 \%$ were females. In addition, $78.3 \%$ of the caregivers were married or living common law, while $14.1 \%$ were widowed, divorced or separated. For the caregivers aged $65+, 41.8 \%$ were males, $70.5 \%$ were married and $26.2 \%$ were separated, divorced or widowed.

Table 2 presents data on the relationship between caregivers and care receivers using dyads as the unit of analysis. Dyads are each combination of a caregiver and a care receiver. Thus, one caregiver could provide care to three care receivers. This would constitute three caregiver-care receiver dyads.) For the younger caregivers, the main recipient of care

65 or older. In this section, we present data for both groups.

Table 1 presents data on the gender, age and marital status of both groups of caregivers. As can be seen, there were an estimated 1,759,378 caregivers aged 45-64 and 302,295 caregivers aged 65 or older in Canada in 2002. (The total of $2,061,673$ caregivers aged $45+$ represents an estimated $18.2 \%$ of the Canadian population aged $45+$.) The actual number of respondents, for survey respondents aged 45-64, was 2,985 and the number of respondents $65+$ was 1,026 . As can be seen in Table 1 , for younger caregivers $62.5 \%$ were aged $45-54$ and was the caregiver's mother, at $41.6 \%$. The next most common categories of care receivers were the caregiver's father $(13.4 \%)$ and mother-in-law (12.4\%) followed by a close friend $(9.2 \%)$ or neighbour $(8.2 \%)$. For caregivers aged $65+$, the pattern was quite different; they primarily cared for a close friend $(29.7 \%)$, their spouse or partner $(23.3 \%)$ or a neighbour $(14.8 \%)$.

Table 3 presents data on the frequency of care provision for each of the major groupings. For the younger caregiver group, the most common activity to be provided on a daily basis was the provision of personal care $(25.3 \%)$ and homemaking activities

Table 5. Total annual, estimated imputed costs* for the contribution of unpaid caregivers aged 45-64

\begin{tabular}{|l|c|c|c|c|}
\hline Type of Service & $\begin{array}{c}\text { Annual Costs } \\
\text { at Hourly Wage } \\
\text { Rates by Type } \\
\text { of Provider }\end{array}$ & $\begin{array}{c}\text { Annual Costs at } \\
\text { Hourly Wage for } \\
\text { Homemakers }\end{array}$ & $\begin{array}{c}\text { Annual Costs at } \\
\text { Hourly Market } \\
\text { Rates by Type } \\
\text { of Provider }\end{array}$ & $\begin{array}{c}\text { Annual Costs } \\
\text { at Hourly } \\
\text { Market Rate for } \\
\text { Homemakers }\end{array}$ \\
\hline $\begin{array}{l}\text { Meal preparation and cleanup, house } \\
\text { cleaning or laundry and sewing }\end{array}$ & $5,012,029,377$ & $5,012,029,378$ & $9,021,652,880$ & $9,021,652,880$ \\
\hline House maintenance or outdoor work & $1,758,535,328$ & $1,248,772,887$ & $3,165,363,590$ & $2,247,791,196$ \\
\hline $\begin{array}{l}\text { Shopping for groceries or other } \\
\text { necessities, providing transportation or } \\
\text { doing banking or bill paying }\end{array}$ & $2,207,132,325$ & $1,885,776,195$ & $3,972,838,185$ & $3,394,397,152$ \\
\hline $\begin{array}{l}\text { Assistance with bathing, toileting, care } \\
\text { of toenails/fingernails, brushing teeth, } \\
\text { shampooing and hair care or dressing }\end{array}$ & $3,110,167,773$ & $1,359,711,004$ & $5,598,301,991$ & $2,447,479,807$ \\
\hline Total & $12,087,864,803$ & $9,506,289,464$ & $21,758,156,646$ & $17,111,321,035$ \\
\hline
\end{tabular}


Table 6. Total annual, estimated imputed costs* for the contribution of unpaid caregivers aged $65+$

\begin{tabular}{|l|c|c|c|c|}
\hline Type of Service & $\begin{array}{c}\text { Annual Costs } \\
\text { at Hourly Wage } \\
\text { Rates by Type } \\
\text { of Provider }\end{array}$ & $\begin{array}{c}\text { Annual Costs } \\
\text { at Hourly } \\
\text { Wage for } \\
\text { Homemakers }\end{array}$ & $\begin{array}{c}\text { Annual Costs at } \\
\text { Hourly Market } \\
\text { Rates by Type } \\
\text { of Provider }\end{array}$ & $\begin{array}{c}\text { Annual Costs } \\
\text { at Hourly } \\
\text { Market Rate for } \\
\text { Homemakers }\end{array}$ \\
\hline $\begin{array}{l}\text { Meal preparation and cleanup, house } \\
\text { cleaning or laundry and sewing }\end{array}$ & $1,071,818,050$ & $1,071,818,050$ & $1,929,272,489$ & $1,929,272,489$ \\
\hline House maintenance or outdoor work & $116,290,482$ & $82,580,315$ & $209,322,868$ & $148,644,567$ \\
\hline $\begin{array}{l}\text { Shopping for groceries or other } \\
\text { necessities, providing transportation or } \\
\text { doing banking or bill paying }\end{array}$ & $485,467,794$ & $414,784,198$ & $873,842,030$ & $746,611,556$ \\
\hline $\begin{array}{l}\text { Assistance with bathing, toileting, care } \\
\text { of toenails/fingernails, brushing teeth, } \\
\text { shampooing and hair care or dressing }\end{array}$ & $1,358,392,096$ & $593,865,288$ & $2,445,105,772$ & $1,068,957,518$ \\
\hline Total & $3,031,968,422$ & $2,163,047,850$ & $5,457,543,160$ & $3,893,486,130$ \\
\hline
\end{tabular}

*In 2007 dollars.

Table 7. Total costs* extrapolated to 2007 for all caregivers ${ }^{\dagger}$

\begin{tabular}{|c|c|c|c|c|}
\hline & $\begin{array}{c}\text { Annual Costs at } \\
\text { Hourly Wage Rates } \\
\text { by Type of Provider }\end{array}$ & $\begin{array}{c}\text { Annual Costs at } \\
\text { Hourly Wage for } \\
\text { Homemakers }\end{array}$ & $\begin{array}{c}\text { Annual Costs at } \\
\text { Hourly Market Rates } \\
\text { by Type of Provider }\end{array}$ & $\begin{array}{c}\text { Annual Costs at } \\
\text { Hourly Market Rate } \\
\text { for Homemakers }\end{array}$ \\
\hline Total & $17,387,808,209$ & $13,419,737,911$ & $31,298,054,777$ & $24,155,528,240$ \\
\hline
\end{tabular}

*In 2007 dollars.

${ }^{\dagger} 45-64$ and $65+$.

(23.3\%). The activity most often provided on a monthly basis or less was home maintenance and/or outdoor work $(63.7 \%)$. The pattern was similar for caregivers aged $65+$, but they were much more likely to provide assistance on a daily basis related to personal care $(60.7 \%)$ and homemaking activities (51.6\%).

In terms of the time provided by unpaid caregivers, it was found that the average hours of care provided per week, per dyad (i.e., each combination of caregiver and care receiver), for the categories of service included in the analysis for people aged 45 or older who were caring for people 65 years of age and older ranged from 7.9 to 10.4 hours of care per week (Table 4). Unfortunately, it is not possible to make direct comparisons with the broader literature as the hours of care provided are usually dependent on the level of care needs of the client. Thus, any comparisons would require that data be standardized to the level of need of the care recipients. Furthermore, other studies were not limited to caregivers $45+$ caring for care receivers $65+$.
Tables 5 and 6 present data on the annual, estimated imputed costs for unpaid caregivers, using the four costing scenarios noted above. From Tables 5 and 6, one can calculate the following overall, annual imputed costs for caregivers aged 45-64 and $65+$.

- Annual costs at hourly wage rates by type of provider: $\$ 15,119,833,225$

- Annual costs at hourly wage for homemakers: $\$ 11,696,337,496$

- Annual costs at hourly market rates by type of provider: $\$ 27,215,699,806$

- Annual costs at hourly market rate for homemakers: $\$ 21,004,807,165$

It is our view that the most appropriate cost estimate would be that for homemakers costed at the hourly market rate. Extrapolating the growth in population from 2002 to 2007 at $11.5 \%$, the estimated imputed cost for the estimated 2007 population for caregivers 45-64 and 65+ using 2007 unit costs for homemakers would be $\$ 24,155,528,240$ (Table 7). Thus, a reasonably conservative estimate of the imputed economic contribution of unpaid caregivers for Canada, for 2009, would be $\$ 25-\$ 26$ billion.

\section{Conclusion}

This study, on estimating the replacement costs of unpaid care in Canada, clearly indicates that unpaid caregivers contribute much to Canadian society, its economy and the well-being of its citizens. And they do so, by and large, willingly.

From a broad policy perspective, decision makers should be advised that providing care to loved ones is something that is typically valued by caregivers and care recipients alike and that many caregivers would prefer to provide care themselves rather 
than have paid care providers come into their homes (Chappell et al. 2001; Horowitz 1985). This factor needs to be recognized as government explores policy options regarding support for unpaid caregivers going forward.

This study has also prompted the consideration of future research related to this topic. Future research topics could include the following:

- Validation of the methodology to convert hourly salaries to market rates;

- Development of cost estimates for caregivers and care receivers of all ages;

- Regional analyses regarding patterns of care provision by unpaid care providers, and comparative costs, across Canada; and

- Differential patterns of care provision to different types of care receivers, by different types of care providers.

While this study presented a number of methodological challenges, it is our view that the findings presented in this paper constitute a sound basis for future planning and policy formulation. $\mathrm{HQ}$

\section{Acknowledgement and Disclaimer}

Funding for this project was provided by Human Resources and Skills Development Canada. This article presents key findings from this project. The more detailed report on which this article is based, titled Unpaid Care Givers in Canada: Replacement Costs Estimates (Hollander et al. 2008), is available at http://www. hollanderanalytical.com. The opinions expressed in this article are those of the authors and do not necessarily represent the views, or policies, of Human Resources and Skills Development Canada.

\section{References}

Access Economics Pty Limited. 2005. The Economic Value of Informal Care. Kingston, Australia: Access Economics.

Andersson, A., L.-A. Levin and B.G. Emtinger. 2002. "The Economic Burden of Informal Care.” International Journal of Technology Assessment in Health Care 18(1): 46-54.

Brouwer, W.B., M.A. Koopmanschap and F.F Rutten. 1998. "Patient and Informal Caregiver Time in Cost-Effectiveness Analysis: A Response to the Recommendations of the Washington Panel." International Journal of Technology Assessment in Health Care 14(3): 505-13.

Buckner, L. and S. Yeandle. 2007. Valuing Carers: Calculating the Value of Unpaid Care. London, England: Carers UK.

Chappell, N.L., B.H. Dlitt, M.J. Hollander, J.A. Miller and C. McWilliam. 2004. "Comparative Costs of Home Care and Residential Care.” The Gerontologist 44(3): 389-400.

Chappell, N.L., R.C. Reid and E. Dow. 2001. "Respite Reconsidered: A Typology of Meanings Based on the Caregiver's Point of View." Journal of Aging Studies 15(2): 201-16.

Fast, J.E. and J.A. Frederick. 1999, October. Informal Caregiving: Is It Really Cheaper? Paper presented at the International Association of Time Use Researchers Conference, Colchester, UK.
Gibson, M.J. and A. Houser. 2007a. AARP Data Digest. Valuing the Invaluable: A New Look at the Economic Value of Family Caregiving (Data Update). Washington, DC: American Association of Retired Persons.

Gibson, M.J. and A. Houser. 2007b. AARP Issue Brief. Valuing the Invaluable: A New Look at the Economic Value of Family Caregiving. Washington, DC: American Association of Retired Persons.

Harrow, B.S., D.F. Mahoney, A.B. Mendelsohn, M.G. Ory, D.W. Coon, S.H. Belle and L.O Nichols. 2004. "Variation in Cost of Informal Caregiving and Formal-Service Use for People with Alzheimer's Disease." American Journal of Alzheimer's Disease and Other Dementias 19: 299-308.

Hollander, M.J., G. Liu and N. Chappell. 2008. Unpaid Caregivers in Canada: Replacement Costs Estimates. Victoria, BC: Hollander Analytical Services Ltd.

Holzhausen, E. 2002. Without Us...? Calculating the Value of Carers Support. London, England: Carers UK.

Horowitz, A. 1985. "Family Caregiving to the Frail Elderly." In C. Eisdorfer, ed., Annual Review of Gerontology and Geriatrics (Vol. 5). New York: Guilford Press.

Langa, K.M., N.H. Fultz, S. Saint, M.U. Kabeto and A.R. Herzog. 2002a. "Informal Caregiving Time and Costs for Urinary Incontinence in Older Individuals in the United States." Journal of the American Geriatrics Society 50: 733-37.

Langa, K.M., S. Vijan, R.A. Hayward, M.E. Chernewm, C.S. Blaum, M.U. Kabeto, D.R. Weir, S.J. Katz, R.J. Willis and A.M. Fendrick. 2002b. "Informal Caregiving for Diabetes and Diabetic Complications among Elderly Americans." Journals of Gerontology. Series B: Psychological Sciences and Social Sciences 57(3): S177-86.

Moore, M.J., C.W. Zhu and E.C. Clipp. 2001. "Informal Costs of Dementia Care: Estimates from the National Longitudinal Caregiver Study." Journals of Gerontology. Series B: Psychological Sciences and Social Sciences 56(4): S219-28.

National Family Caregivers Association and Family Caregiver Alliance. 2006. Prevalence, Hours and Economic Value of Family Caregiving, Updated State-by-State Analysis of 2004 National Estimates. Kensington, MD: National Family Caregivers Association; San Francisco, CA: Family Caregiver Alliance.

Statistics Canada. 2001. Canadian Community Health Survey. Ottawa, ON: Author.

Statistics Canada. 2002. 2002 General Social Survey. Cycle 16: Aging and Social Support. Ottawa, ON: Author.

Statistics Canada. 2007. Labour Force Survey. Ottawa, ON: Author.

\section{About the Authors}

Marcus J. Hollander, PhD, is the president of Hollander Analytical Services Ltd., Victoria, British Columbia. You can contact him at 250-384-2776, by fax at 250-389-0105 or by email at marcus@hollanderanalytical.com.

Guiping Liu, PhD, is the research coordinator at the Centre on Aging, University of Victoria, Victoria, British Columbia. Guiping can be reached at 250-721-6368, by fax at 250-721-6499 or by e-mail at guipingl@uvic.ca

Neena L. Chappell, PhD, FRSC, CRC, is the Canada research chair in social gerontology and a professor at the Centre on Aging and the Department of Sociology, University of Victoria. She can be reached at 250-472-4465, by fax at 250-721-6499 or by e-mail at nlc@uvic.ca. 